UDC 546.732/735.548.55

\author{
O.V. Petrenko ${ }^{a}$, P.G. Nagorny ${ }^{a}$, V.I. Maksyn ${ }^{b}$, R.V. Lavrik ${ }^{b}$, V.M. Galimova ${ }^{b}$
}

\title{
MIXED ANIONIC DOUBLE SODIUM-COBALT(II) DIORTHODIPHOSPHATE: STRUCTURE AND GROWING OF SINGLE-CRYSTALS
}

\author{
${ }^{a}$ Taras Shevchenko National University of Kyiv, Kyiv, Ukraine \\ b National University of Life and Environmental Sciences of Ukraine, Kyiv, Ukraine
}

\begin{abstract}
The solubility of cobalt oxide was determined in the melts of the system $\mathrm{Na}_{2} \mathrm{O}-\mathrm{P}_{2} \mathrm{O}_{5}-\mathrm{CoO}-\mathrm{NaF}$ in a wide range of molar ratios $\mathrm{Na}_{2} \mathrm{O}: \mathrm{P}_{2} \mathrm{O}_{5}(0.5-2.0)$ and temperatures of $800-900^{\circ} \mathrm{C}$ at the sodium fluoride content of $10 \mathrm{wt} . \%$ and $20 \mathrm{wt} . \%$. The region of existence and optimal conditions for growing monocrystals of complex phosphate $\mathrm{Na}_{4} \mathrm{Co}_{3}\left(\mathrm{PO}_{4}\right)_{2} \mathrm{P}_{2} \mathrm{O}_{7}$ in the melts of the system $\mathrm{Na}_{2} \mathrm{O}-\mathrm{P}_{2} \mathrm{O}_{5}-\mathrm{CoO}-\mathrm{NaF}$ was found out. The synthesized compound was investigated using a number of physicochemical methods (IR spectroscopy, diffuse reflection spectroscopy, $\mathrm{X}$-ray phase analysis, $\mathrm{X}$-ray structure analysis and differential thermal analysis). The complete chemical analysis of the synthesized compound was performed and the melting temperature was determined $765^{\circ} \mathrm{C}$, without decomposition). The X-ray diffraction analysis of $\mathrm{Na}_{4} \mathrm{Co}_{3}\left(\mathrm{PO}_{4}\right)_{2} \mathrm{P}_{2} \mathrm{O}_{7}$ single crystals was carried out and the unit lattice parameters were determined. Phosphate crystals belong to the rhombic crystal system, sp. gr. Pna $2_{1}$; crystal lattice parameters are as follows: $\mathrm{a}=18.021(1)$ $\AA, \mathrm{b}=10.389(2) \AA, \mathrm{c}=6.532(2) \AA, \mathrm{V}=1222.47(1) \AA^{3}, \mathrm{Z}=4, \mathrm{c}_{\text {calc }}=3.47 \mathrm{~g} \mathrm{~cm}^{-3}$. The following specific features of the structure of complex phosphate $\mathrm{Na}_{4} \mathrm{Co}_{3}\left(\mathrm{PO}_{4}\right)_{2} \mathrm{P}_{2} \mathrm{O}_{7}$ have been established: the presence of conduction channels for the sodium ion along the oy axis and the presence of differently coordinated $\mathrm{Na}$ and Co polyhedra with an uncharacteristic coordination number. The optimal conditions for the growth of complex phosphate single crystals with a high weight yield were selected. The use of the synthesized compound $\mathrm{Na}_{4} \mathrm{Co}_{3}\left(\mathrm{PO}_{4}\right)_{2} \mathrm{P}_{2} \mathrm{O}_{7}$ as a functional material with ion conductivity was suggested.
\end{abstract}

Keywords: double phosphate, IR-spectroscopy, X-ray structure analysis, X-ray phase analysis, growing of single crystals, parameters of crystal lattice.

DOI: $10.32434 / 0321-4095-2021-138-5-90-96$

\section{Introduction}

The attention of many researchers is focused on the synthesis of functional materials based on phosphate compounds in mono- and polycrystalline states. Their applications include piezoelectric, ferroelectric and pyroelectric materials; they are used as accelerants, laser and optic materials, luminophores and ionic conductors, etc. [1,2]. Phosphate compounds can demonstrate valuable electrophysical properties and being a «cost-effective material» they are successfully used in different areas of electrical engineering [3-5]. Solid-state synthesis [6], synthesis of polyphosphoric acids $[7,8]$, water and thermal syntheses are the most known among the widespread methods of production of double phosphates [9-11]. However, the best results from the point of view of clarity, sizes, quality and characteristics of substances implies the method of growing double phosphates monocrystals from solutions-fluxes of alkali metals phosphate systems. Using this method, the whole series of phosphates $\mathrm{M}^{\mathrm{I}} \mathrm{M}^{\mathrm{II}}\left(\mathrm{PO}_{3}\right)_{3}, \mathrm{M}^{\mathrm{I}} \mathrm{M}^{\mathrm{II}} \mathrm{PO}_{4}, \mathrm{M}_{2}{ }_{2} \mathrm{M}^{\mathrm{II}} \mathrm{P}_{2} \mathrm{O}_{7}, \mathrm{M}_{2}^{\mathrm{I}} \mathrm{M}^{\mathrm{II}}\left(\mathrm{PO}_{3}\right)_{4}$, $\mathrm{M}_{2}^{\mathrm{I}} \mathrm{M}^{\mathrm{II}}\left(\mathrm{PO}_{3}\right)_{4}, \mathrm{M}^{\mathrm{I}} \mathrm{M}_{4}{ }_{4}\left(\mathrm{PO}_{4}\right)_{3}, \mathrm{M}_{3}^{\mathrm{I}} \mathrm{M}^{\mathrm{III}}\left(\mathrm{PO}_{4}\right)_{2}$, $\mathrm{M}_{3}{ }_{3} \mathrm{M}^{\mathrm{III}}{ }_{2}\left(\mathrm{PO}_{4}\right)_{3}, \mathrm{M}^{\mathrm{I}} \mathrm{M}^{\mathrm{III}} \mathrm{P}_{2} \mathrm{O}_{7}$ and $\mathrm{M}^{\mathrm{I}} \mathrm{M}^{\mathrm{III}}\left(\mathrm{PO}_{3}\right)_{4}[3-$ $7,12]$ were obtained which became the basis for development of functional materials for multifaceted purposes. Doping and metal substitution in phosphate matrices and backbones became a convenient «tool» for getting various compound properties [13].

The investigation of such substances as $\mathrm{Na}_{4} \mathrm{M}_{3}\left(\mathrm{PO}_{4}\right)_{2} \mathrm{P}_{2} \mathrm{O}_{7}$ (where $\mathrm{M}=\mathrm{Mn}, \mathrm{Fe}, \mathrm{Co}$, and $\mathrm{Ni}$ ) [14], which demonstrated the characteristics of highvoltage ion batteries, has gained a great attention in the past couple of years. Since the materials of above- 
mentioned type show large cyclicality and duration of operations, the search for methods of substitution of $\mathrm{Fe}$ and $\mathrm{Ni}$ in the structure is in progress. In our opinion, substitution of sodium atoms by lithium ones could greatly improve the chances of producing materials based on phosphate compounds of this type.

The aim of this research was to find a convenient, express and cheap way of getting monocrystals of a new $\mathrm{Na}_{4} \mathrm{Co}_{3}\left(\mathrm{PO}_{4}\right)_{2} \mathrm{P}_{2} \mathrm{O}_{7}$ complex phosphate and investigate its chemical properties.

\section{Experimental}

$\mathrm{Na}_{4} \mathrm{Co}_{3}\left(\mathrm{PO}_{4}\right)_{2} \mathrm{P}_{2} \mathrm{O}_{7}$ complex double phosphate was synthesized from the fluxes of $\mathrm{Na}_{2} \mathrm{O}-\mathrm{P}_{2} \mathrm{O}_{5}-\mathrm{CoO}$ system at slow cooling (with the rate of $10^{\circ} \mathrm{C}$ per hour) at the temperature range of $1000-650^{\circ} \mathrm{C}$. Homogeneous fluxes $\left(\right.$ at $\left.950^{\circ} \mathrm{C}\right)$ with output molar ratio $\mathrm{Na}_{2} \mathrm{O}: \mathrm{P}_{2} \mathrm{O}_{5}$ equal to 1.1 were saturated with $\mathrm{CoO}$ (25 wt.\%) using intimate, intermittent mixing during 3-4 hours, raised temperature and crystallized crystals in the above-mentioned temperature range. The obtained monocrystals were washed out from the flux residue using the solution of light-salted acid, washed in flowing water and dried at ambient temperature. The outcome of monocrystals was 40$45 \mathrm{wt} . \%$, the sizes being ranged from 0.1 to $3.5 \mathrm{~mm}$.

The investigation of crystal structure of $\mathrm{Na}_{4} \mathrm{Co}_{3}\left(\mathrm{PO}_{4}\right)_{2} \mathrm{P}_{2} \mathrm{O}_{7}$ was conducted on diffractometer «Siemens P3/PC» $\left(\mathrm{MoK}_{\alpha}\right.$-radiation, graphite monochromator). The reduced structure was solved by direct method and the unit cell parameters were refined using the full-matrix least squares on 16 reflexes at $28^{0} \leq \theta \leq 42^{0}$. Phosphate crystals belong to the rhombic crystal system, sp. gr. Pna2 ${ }_{1}$; the crystal lattice parameters are as follows: $\mathrm{a}=18.021(1) \AA$, $\mathrm{b}=10.389(2) \AA, \mathrm{c}=6.532(2) \AA, \mathrm{V}=1222.47(1) \AA^{3}$, $\mathrm{Z}=4, \mathrm{c}_{\text {calc }}=3.47 \mathrm{~g} \mathrm{~cm}^{-3}$. Integrated intensities were measured using the $2 \theta: \theta$ method at $6^{0} \leq 2 \theta \leq 62^{\circ}$ and scanning rate of 2-18 degree per minute. As a result of experiment, a total of 1122 reflections were obtained, 1078 independent reflections with $\mathrm{I}>6 \delta(\mathrm{I})$ were used for calculations and specifying the $\mathrm{Na}_{4} \mathrm{Co}_{3}\left(\mathrm{PO}_{4}\right)_{2} \mathrm{P}_{2} \mathrm{O}_{7}$ structure. In the data file, the correction for Lorentz factor and polarization was introduced, and the experimental correction for absorption was conducted. The structure calculation was performed using software SHELX-97. End value

Table 1

Coordinates of atoms and equivalent thermal corrections for the $\mathrm{Na}_{4} \mathrm{Co}_{3}\left(\mathrm{PO}_{4}\right)_{2} \mathrm{P}_{2} \mathrm{O}_{7}$ structure

\begin{tabular}{|c|c|c|c|c|}
\hline Atom & $\begin{array}{c}\text { Coordinates of atoms } \\
\mathrm{x} / \mathrm{a}\left(\times 10^{4}\right)\end{array}$ & $\begin{array}{c}\text { Coordinates of atoms } \\
\mathrm{y} / \mathrm{b}\left(\times 10^{4}\right)\end{array}$ & $\begin{array}{l}\text { Coordinates of atoms } \\
\mathrm{z} / \mathrm{c}\left(\times 10^{4}\right)\end{array}$ & $\begin{array}{l}\text { Equivalent thermal corrections } \\
\qquad\left(\mathrm{U}_{\mathrm{eq}}\right),\left(\AA^{2} \times 10^{3}\right)\end{array}$ \\
\hline $\operatorname{Co}(1)$ & $3614(5)$ & $47(1)$ & 0 & $4(1)$ \\
\hline $\operatorname{Co}(2)$ & $1693(6)$ & $-47(1)$ & $5113(1)$ & $4(1)$ \\
\hline $\operatorname{Co}(3)$ & $2406(6)$ & $2560(1)$ & $2345(31)$ & $4(1)$ \\
\hline $\mathrm{Na}(1)$ & $2968(2)$ & $2514(3)$ & $-2416(7)$ & $14(1)$ \\
\hline $\mathrm{Na}(2)$ & $4609(2)$ & $-5400(4)$ & $5657(7)$ & $14(1)$ \\
\hline $\mathrm{Na}(3)$ & $3899(2)$ & $-2624(4)$ & $3242(7)$ & $12(1)$ \\
\hline $\mathrm{Na}(4)$ & $4934(2)$ & $264(3)$ & $-2765(8)$ & $10(2)$ \\
\hline $\mathrm{P}(1)$ & $3208(1)$ & $120(2)$ & $4929(5)$ & $4(1)$ \\
\hline $\mathrm{P}(2)$ & $2301(1)$ & $-24(2)$ & $43(5)$ & $4(1)$ \\
\hline $\mathrm{P}(3)$ & $9316(2)$ & $7500(1)$ & $4209(1)$ & $4(1)$ \\
\hline $\mathrm{P}(4)$ & $6848(2)$ & $10925(1)$ & $2858(1)$ & $3(1)$ \\
\hline $\mathrm{O}(1)$ & $13194(5)$ & $3462(4)$ & $1592(2)$ & $10(1)$ \\
\hline $\mathrm{O}(2)$ & $12864(5)$ & $7016(4)$ & $2043(2)$ & $12(1)$ \\
\hline $\mathrm{O}(3)$ & $9070(5)$ & $5410(4)$ & $2383(2)$ & $17(1)$ \\
\hline $\mathrm{O}(4)$ & $10375(5)$ & $6813(4)$ & $907(2)$ & $16(1)$ \\
\hline $\mathrm{O}(5)$ & $6411(5)$ & $6178(4)$ & $375(2)$ & $14(1)$ \\
\hline $\mathrm{O}(6)$ & $9180(5)$ & $8428(4)$ & $457(2)$ & $11(1)$ \\
\hline $\mathrm{O}(7)$ & $6146(5)$ & $9772(4)$ & $803(2)$ & $10(1)$ \\
\hline $\mathrm{O}(8)$ & $8240(5)$ & $8583(4)$ & $4987(2)$ & $18(1)$ \\
\hline $\mathrm{O}(9)$ & $12243(5)$ & $6408(4)$ & $4145(2)$ & $15(1)$ \\
\hline $\mathrm{O}(10)$ & $7725(5)$ & $6053(4)$ & $4063(2)$ & $15(1)$ \\
\hline $\mathrm{O}(11)$ & $9061(5)$ & 9403(4) & $3432(2)$ & $14(1)$ \\
\hline $\mathrm{O}(12)$ & $5623(5)$ & $12879(4)$ & $3322(2)$ & $14(1)$ \\
\hline $\mathrm{O}(13)$ & $8401(5)$ & $11358(4)$ & $2041(2)$ & $10(1)$ \\
\hline $\mathrm{O}(14)$ & $4809(5)$ & $9760(4)$ & $2796(2)$ & $12(1)$ \\
\hline $\mathrm{O}(15)$ & $4145(3)$ & $-3741(6)$ & $10068(9)$ & $8(2)$ \\
\hline
\end{tabular}


of divergence factor was $\mathrm{R}_{\mathrm{w}}=0.024$.

IR spectroscopy study was performed by means of UR-20 and UR-10 equipment (Carl Zeiss) by the method involving the use of $\mathrm{KBr}$ pressed disc.

Thermal investigations of the synthesized phosphate were conducted using the derivatograph Q-1500 «Paulik» (Hungary). The sample was heated at $20-1000^{\circ} \mathrm{C}$ under dynamic conditions of heating in platinum cylindrical crucibles (the weight of compound was $0.293 \mathrm{~g}$, the heating rate was 5 degrees per minute).

The spectra of diffuse reflection of polycrystalline samples were collected using spectrophotometer «Specord 40» within the range of wave numbers of 50000-12000 $\mathrm{cm}^{-1}$.

\section{Results and discussion}

Positional parameters of atoms with standard deviations in the structure under study are presented in Table 1. The structure contains three structurally independent nickel atoms that have different coordinating oxygen atoms. $\mathrm{Co}(1)$ and $\mathrm{Co}(2)$ polyhedra have a form of a broken octahedron with coordination number of cobalt 6 . $\mathrm{Co}(3)$ atom creates tetragonal pyramid and has coordination number 5 (Table 2).

Tetrahedra $\left[\mathrm{PO}_{4}\right]$ that create two orthophosphate groups and nickel polyhedra are merged through co-vertices and co-edges in imperfect spheres, perpendicular to direction [100]. Chains from $\mathrm{Co}(2) \mathrm{O}_{6}-\mathrm{Co}(3) \mathrm{O}_{5}$ polyhedra which are merged at vertices by $\mathrm{O}(3)$ and $\mathrm{O}(4)$ atoms and parallel the direction can be distinguished [010]. They are intersected by the chains of $\mathrm{Co}(1) \mathrm{O}_{6}-\mathrm{Co}(3) \mathrm{O}_{5}$ polyhedra that have the common vertices of $\mathrm{O}(6)$ and $\mathrm{O}(7)$ atoms and oriented alongside [011]. Diphosphate groups $\left[\mathrm{P}_{2} \mathrm{O}_{7}\right]$ merge abovementioned

Table 2

Lengths of bonds in $\mathrm{Na}_{4} \mathrm{Co}_{3}\left(\mathrm{PO}_{4}\right)_{2} \mathrm{P}_{2} \mathrm{O}_{7}$ structure

\begin{tabular}{c|c|c|c}
\hline Bond & Lengths of bonds, $\AA$ & Bond & Lengths of bonds, $\AA$ \\
\hline $\mathrm{Co}(1)-\mathrm{O}(1)$ & $2.068(8)$ & $\mathrm{Na}(3)-\mathrm{O}(1)$ & $2.316(6)$ \\
\hline $\mathrm{Co}(1)-\mathrm{O}(6)$ & $2.110(7)$ & $\mathrm{Na}(3)-\mathrm{O}(1)$ & $2.407(9)$ \\
\hline $\mathrm{Co}(1)-\mathrm{O}(7)$ & $2.120(8)$ & $\mathrm{Na}(4)-\mathrm{O}(1)$ & $2.479(6)$ \\
\hline $\mathrm{Co}(1)-\mathrm{O}(2)$ & $2.070(9)$ & $\mathrm{Na}(4)-\mathrm{O}(2)$ & $2.334(8)$ \\
\hline $\mathrm{Co}(1)-\mathrm{O}(14)$ & $2.072(6)$ & $\mathrm{Na}(4)-\mathrm{O}(9)$ & $2.311(6)$ \\
\hline $\mathrm{Co}(1)-\mathrm{O}(9)$ & $2.111(8)$ & $\mathrm{Na}(4)-\mathrm{O}(14)$ & $2.332(9)$ \\
\hline $\mathrm{Co}(2)-\mathrm{O}(3)$ & $2.062(8)$ & $\mathrm{Na}(4)-\mathrm{O}(9)$ & $2.238(6)$ \\
\hline $\mathrm{Co}(2)-\mathrm{O}(4)$ & $2.224(7)$ & $\mathrm{Na}(4)-\mathrm{O}(14)$ & $2.559(6)$ \\
\hline $\mathrm{Co}(2)-\mathrm{O}(5)$ & $2.089(8)$ & $\mathrm{P}(1)-\mathrm{O}(1)$ & $1.520(3)$ \\
\hline $\mathrm{Co}(2)-\mathrm{O}(8)$ & $2.054(9)$ & $\mathrm{P}(1)-\mathrm{O}(2)$ & $1.536(3)$ \\
\hline $\mathrm{Co}(2)-\mathrm{O}(11)$ & $2.039(6)$ & $\mathrm{P}(1)-\mathrm{O}(3)$ & $1.557(3)$ \\
\hline $\mathrm{Co}(2)-\mathrm{O}(15)$ & $2.032(8)$ & $\mathrm{P}(1)-\mathrm{O}(4)$ & $1.560(2)$ \\
\hline $\mathrm{Co}(3)-\mathrm{O}(4)$ & $2.052(8)$ & $\mathrm{P}(2)-\mathrm{O}(5)$ & $1.536(3)$ \\
\hline $\mathrm{Co}(3)-\mathrm{O}(7)$ & $2.004(7)$ & $\mathrm{P}(2)-\mathrm{O}(6)$ & $1.557(1)$ \\
\hline $\mathrm{Co}(3)-\mathrm{O}(3)$ & $2.039(8)$ & $\mathrm{P}(2)-\mathrm{O}(7)$ & $1.521(3)$ \\
\hline $\mathrm{Co}(3)-\mathrm{O}(13)$ & $2.084(9)$ & $\mathrm{P}(2)-\mathrm{O}(8)$ & $1.533(3)$ \\
\hline $\mathrm{Co}(3)-\mathrm{O}(6)$ & $2.039(6)$ & $\mathrm{P}(3)-\mathrm{O}(9)$ & $1.528(1)$ \\
\hline $\mathrm{Na}(1)-\mathrm{O}(7)$ & $2.379(6)$ & $\mathrm{P}(1)-\mathrm{O}(3)$ & $1.557(3)$ \\
\hline $\mathrm{Na}(1)-\mathrm{O}(2)$ & $2.534(6)$ & $\mathrm{P}(1)-\mathrm{O}(4)$ & $1.536(2)$ \\
\hline $\mathrm{Na}(1)-\mathrm{O}(4)$ & $2.411(6)$ & $\mathrm{P}(2)-\mathrm{O}(5)$ & $1.557(1)$ \\
\hline $\mathrm{Na}(1)-\mathrm{O}(6)$ & $2.632(6)$ & $\mathrm{P}(2)-\mathrm{O}(6)$ & $1.521(3)$ \\
\hline $\mathrm{Na}(1)-\mathrm{O}(5)$ & $2.538(6)$ & $\mathrm{P}(2)-\mathrm{O}(7)$ & $1.533(3)$ \\
\hline $\mathrm{Na}(1)-\mathrm{O}(5)$ & $2.359(6)$ & $\mathrm{P}(2)-\mathrm{O}(8)$ & $1.528(1)$ \\
\hline $\mathrm{Na}(1)-\mathrm{O}(11)$ & $2.547(8)$ & $\mathrm{P}(3)-\mathrm{O}(9)$ & $1.498(2)$ \\
\hline $\mathrm{Na}(2)-\mathrm{O}(5)$ & $2.377(8)$ & $\mathrm{P}(3)-\mathrm{O}(10)$ & $1.503(3)$ \\
\hline $\mathrm{Na}(2)-\mathrm{O}(12)$ & $2.616(6)$ & $\mathrm{P}(3)-\mathrm{O}(11)$ & $1.650(3)$ \\
\hline $\mathrm{Na}(2)-\mathrm{O}(10)$ & $2.478(6)$ & $\mathrm{P}(3)-\mathrm{O}(12)$ & $1.630(2)$ \\
\hline $\mathrm{Na}(2)-\mathrm{O}(10)$ & $2.435(6)$ & $\mathrm{P}(4)-\mathrm{O}(12)$ & $1.512(3)$ \\
\hline $\mathrm{Na}(2)-\mathrm{O}(15)$ & $2.457(6)$ & $\mathrm{P}(4)-\mathrm{O}(13)$ & $1.513(3)$ \\
\hline $\mathrm{Na}(3)-\mathrm{O}(1)$ & $2.597(6)$ & $\mathrm{P}(4)-\mathrm{O}(14)$ & \\
\hline $\mathrm{Na}(3)-\mathrm{O}(1)$ & $2.352(6)$ & $\mathrm{P}(4)-\mathrm{O}(15)$ & \\
\hline $\mathrm{Na}(3)-\mathrm{O}(1)$ & $2.404(8)$ & & \\
\hline & & & \\
\hline & & & \\
\hline & & & \\
\hline & & & \\
\hline & & & \\
\hline
\end{tabular}


spheres in a backbone whose voids contain sodium atoms (Fig. 1).

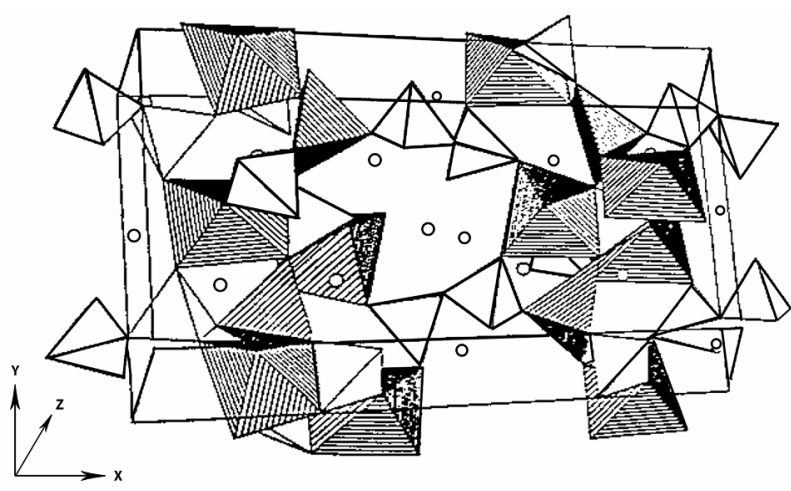

Fig. 1. Projection of $\mathrm{Na}_{4} \mathrm{Co}_{3}\left(\mathrm{PO}_{4}\right)_{2} \mathrm{P}_{2} \mathrm{O}_{7}$ structure

We have to admit that $\mathrm{Co}-\mathrm{O}$ bonding distances in octahedra (mean $\sim 2.085 \AA$ ) are fully coordinated to nickel (II) (coordination number 6). In $\mathrm{Co}(3) \mathrm{O}_{5}$ polyhedra, $\mathrm{Co}^{-} \mathrm{O}$ average bonding distance is $2.040 \AA$, with that the length of $\mathrm{Co}-\mathrm{O}$ at the bottom of pyramid $(0.04-0.09 \AA)$ is shorter than
$\mathrm{Co}(3)-\mathrm{O}(13)$ compound which takes axial vertex.

$\left[\mathrm{PO}_{4}\right]$ and $\left[\mathrm{P}_{2} \mathrm{O}_{7}\right]$ groups (Table 3) are isolated and have a common structure. The angle $\angle \mathrm{P}(3)-$ $\mathrm{O}(12)-\mathrm{P}(4)$ in the nonlinear group is equal to $130.6(4)^{0}$, mean ranges $\mathrm{P}-\mathrm{O}$ is $1.544(2) \AA$, and the mean angle $\angle \mathrm{O}-\mathrm{P}-\mathrm{O}$ is $109.5(1)^{\circ}$. All these values correspond to an almost ideal tetrahedron.

The presence of three different sodium polyhedra with different coordination numbers, $\left[\mathrm{Na}(1) \mathrm{O}_{7}\right],\left[\mathrm{Na}(2) \mathrm{O}_{5}\right],\left[\mathrm{Na}(3) \mathrm{O}_{5}\right]$, and $\left[\mathrm{Na}(4) \mathrm{O}_{6}\right]$ can be regarded as a structure peculiarity. Sodium polyhedra are assembled by common vertices and edges in endless chains that go along the directions [100] and [011] in the structure. In doing so, the direction of sodium polyhedra chains coincides with orientation of the channels in the backbone Co-P. It enables to expect the presence of valuable characteristics of $\mathrm{Na}_{4} \mathrm{Co}_{3}\left(\mathrm{PO}_{4}\right)_{2} \mathrm{P}_{2} \mathrm{O}_{7}$ compound, namely, ionic conductivity.

The chemical composition of the synthesized compound $\mathrm{Na}_{4} \mathrm{Co}_{3}\left(\mathrm{PO}_{4}\right)_{2} \mathrm{P}_{2} \mathrm{O}_{7}$ has been proved by the chemical analysis (Table 4).

Table 5 showed the results of IR spectroscopy

Table 3

Geometric characteristics of phosphate polyhedrons in $\mathrm{Na}_{4} \mathrm{Co}_{3}\left(\mathrm{PO}_{4}\right)_{2} \mathrm{P}_{2} \mathrm{O}_{7}$ structure

\begin{tabular}{|c|c|c|c|c|}
\hline Bond & Lengths of bonds, $\AA$ & \multicolumn{3}{|c|}{ Angle, degree } \\
\hline $\mathrm{P}(1)-\mathrm{O}(1)$ & $1.520(3)$ & & & \\
\hline $\mathrm{P}(1)-\mathrm{O}(2)$ & $1.536(3)$ & $110.4(0.4)$ & & \\
\hline $\mathrm{P}(1)-\mathrm{O}(3)$ & $1.557(3)$ & $108.6(0.4)$ & $113.4(0.4)$ & \\
\hline \multirow[t]{2}{*}{$\mathrm{P}(1)-\mathrm{O}(4)$} & $1.560(2)$ & $115.5(0.4)$ & $106.4(0.4)$ & $102.5(0.4)$ \\
\hline & & $\mathrm{O}(1)$ & $\mathrm{O}(2)$ & $\mathrm{O}(3)$ \\
\hline $\mathrm{P}(2)-\mathrm{O}(5)$ & $1.536(3)$ & & & \\
\hline $\mathrm{P}(2)-\mathrm{O}(6)$ & $1.557(1)$ & $108.4(0.4)$ & & \\
\hline $\mathrm{P}(2)-\mathrm{O}(7)$ & $1.521(3)$ & $114.0(0.4)$ & $101.3(0.4)$ & \\
\hline \multirow[t]{2}{*}{$\mathrm{P}(2)-\mathrm{O}(8)$} & $1.533(3)$ & $110.1(0.4)$ & $113.4(0.4)$ & $109.4(0.4)$ \\
\hline & & $\mathrm{O}(5)$ & $\mathrm{O}(6)$ & $\mathrm{O}(7)$ \\
\hline $\mathrm{P}(3)-\mathrm{O}(9)$ & $1.528(1)$ & & & \\
\hline $\mathrm{P}(3)-\mathrm{O}(10)$ & $1.498(2)$ & $113.7(0,4)$ & & \\
\hline $\mathrm{P}(3)-\mathrm{O}(11)$ & $1.503(3)$ & $115.4(0.4)$ & $114.4(0.4)$ & \\
\hline \multirow[t]{2}{*}{$\mathrm{P}(3)-\mathrm{O}(12)$} & $1.650(3)$ & $106,4(0,4)$ & $105.4(0.4)$ & $105.4(0.4)$ \\
\hline & & $\mathrm{O}(9)$ & $\mathrm{O}(10)$ & $\mathrm{O}(11)$ \\
\hline $\mathrm{P}(4)-\mathrm{O}(12)$ & $1.630(2)$ & & & \\
\hline $\mathrm{P}(4)-\mathrm{O}(13)$ & $1.512(3)$ & $109.7(0.4)$ & & \\
\hline $\mathrm{P}(4)-\mathrm{O}(14)$ & $1.513(3)$ & $105.6(0.4)$ & $113.4(0.4)$ & \\
\hline \multirow[t]{2}{*}{$\mathrm{P}(4)-\mathrm{O}(15)$} & $1.503(3)$ & $102.1(0.4)$ & $116.4(0.4)$ & $111.7(0.4)$ \\
\hline & & $\mathrm{O}(12)$ & $\mathrm{O}(13)$ & $\mathrm{O}(14)$ \\
\hline
\end{tabular}

Table 4

Results of chemical analysis of the synthesized compound

\begin{tabular}{c|c|c|c|c|c}
\hline \multicolumn{2}{c|}{ Content $\mathrm{Na}_{2} \mathrm{O}$, wt. $\%$} & \multicolumn{2}{c|}{ Content $\mathrm{CoO}$, wt. $\%$} & \multicolumn{2}{c}{ Content $\mathrm{P}_{2} \mathrm{O}_{5}, \mathrm{wt} . \%$} \\
\hline calculated & found & calculated & found & calculated & found \\
\hline 19.65 & 20.95 & 44.85 & 43.90 & 35.50 & 36.00 \\
\hline
\end{tabular}


Infrared spectrum of double phosphates

\begin{tabular}{c|c|c}
\hline \multirow{2}{*}{ Characteristic bands } & \multicolumn{2}{|c}{ Frequency, $v, \mathrm{~cm}^{-1}$} \\
\cline { 2 - 3 } & $\mathrm{Na}_{4} \mathrm{Co}_{3}\left(\mathrm{PO}_{4}\right)_{2} \mathrm{P}_{2} \mathrm{O}_{7}$ & $\mathrm{Na}_{4} \mathrm{NiCO}_{3}\left(\mathrm{PO}_{4}\right)_{2} \mathrm{P}_{2} \mathrm{O}_{7}$ \\
\hline$\tau\left(\mathrm{PO}_{3}\right)$ fluct. lattice & $420 \mathrm{w}$. & $420 \mathrm{w}$. \\
\hline$\delta_{\mathrm{s}} \mathrm{P}-\mathrm{O}$ & 500 str., 550 str., 560 sh., 570 str. & 515 str., 525 str., 560 sh. \\
\hline$\delta_{\mathrm{as}}+v \mathrm{MO}$ & $720 \mathrm{w}$. & 590 str. \\
\hline$v_{\mathrm{s}} \mathrm{P}-\mathrm{O}-\mathrm{P}$ & 890 sh., 920 str., $950 \mathrm{w}$. & 890 sh., 935 v. str., 955 v. str. \\
\hline$v_{\mathrm{as}} \mathrm{P}-\mathrm{O}-\mathrm{P}$ & 1085 str., 1100 str. & 1040 str., 1100 str. \\
\hline$v_{\mathrm{s}} \mathrm{PO}_{2}$ & 1170 sh., 1210 sh. & 1150 sh., 1210 sh. \\
\hline$v_{\mathrm{as}} \mathrm{PO}_{2}$ & &
\end{tabular}

of $\mathrm{Na}_{4} \mathrm{Co}_{3}\left(\mathrm{PO}_{4}\right)_{2} \mathrm{P}_{2} \mathrm{O}_{7}$ double phosphate. It was found out that infrared spectrum of absorption corresponds to $\mathrm{Na}_{4} \mathrm{Ni}_{3}\left(\mathrm{PO}_{4}\right)_{2} \mathrm{P}_{2} \mathrm{O}_{7}$ [15], which proves the isostructirality of substances. Significant waves of fluctuation which are $\tau\left(\mathrm{PO}_{3}\right) ; \delta_{\mathrm{s}}, \delta_{\text {as }}(\mathrm{P}-\mathrm{O})+v(\mathrm{MO})$ $-500-600 \mathrm{~cm}^{-1} ; v_{\mathrm{s}}(\mathrm{P}-\mathrm{O}-\mathrm{P})$ and $v_{\mathrm{as}}(\mathrm{P}-\mathrm{O}-\mathrm{P})-$ $700-1000 \mathrm{~cm}^{-1}$ are typical of phosphates which contain $\left[\mathrm{P}_{2} \mathrm{O}_{7}\right]$ group.

Having conducted derivatographic research we determined that double phosphate has a phase transition at $755^{\circ} \mathrm{C}$, it fluxes without decomposition at $765^{\circ} \mathrm{C}$.

Sodium atoms in the volumetric backbone of $\mathrm{Na}_{4} \mathrm{Co}_{3}\left(\mathrm{PO}_{4}\right)_{2} \mathrm{P}_{2} \mathrm{O}_{7}$ phosphate compound play a very important role: they are directly involved in the construction of phosphatic-cobalt backbone. It is unambiguously traced in the projected structure on the square [001] (Fig. 2). $\mathrm{Na}(2) \mathrm{O}_{5}$ and $\mathrm{Na}(3) \mathrm{O}_{5}$ sodium polyhedra have uncharacteristic coordination numbers and that is why we can conditionally believe that $\mathrm{Na}(2)$ and $\mathrm{Na}(3)$ atoms have oxygen surrounding from 6 atoms, taking into consideration that oxygen atoms are located at a longer distance. $\mathrm{Na}(1)$ atom creates imperfect $\mathrm{Na}(1) \mathrm{O}_{7}$ polyhedra through contacting with two isolated groups $\left[\mathrm{PO}_{4}\right]\left(\mathrm{P}(1) \mathrm{O}_{4}\right.$ and $\left.\mathrm{P}(2) \mathrm{O}_{4}\right)$. $\mathrm{Na}(1)$ and $\mathrm{Na}(2)$ atoms contacting through $\mathrm{O}(5)$ merged by $\mathrm{O}(10)-\mathrm{O}(15)$ edge and through $\mathrm{O}(1)$ atom from $\mathrm{Na}(4) \mathrm{O}_{6}$ polyhedra into the endless chain along the oy axis. At this conductivity, a «channel» for sodium ion (similar channels also exist along direction [011]) is created), sodium atoms have not any contacts along the oz axis. These «branched» bonds of alkali metal atoms influence greatly the formation of $\mathrm{Na}_{4} \mathrm{Co}_{3}\left(\mathrm{PO}_{4}\right)_{2} \mathrm{P}_{2} \mathrm{O}_{7}$ backbone structure.

The diffuse reflection spectrum of $\mathrm{Na}_{4} \mathrm{Co}_{3}\left(\mathrm{PO}_{4}\right)_{2} \mathrm{P}_{2} \mathrm{O}_{7}$ has a characteristic shape typical of $\mathrm{Co}$ (II) high-spin compounds of octahedroid-type. In accordance with the energy scheme of $\mathrm{Co}^{2+}$ levels of polyoctahedroid symmetry, the following band ratio can be foreseen. The more intensive absorption

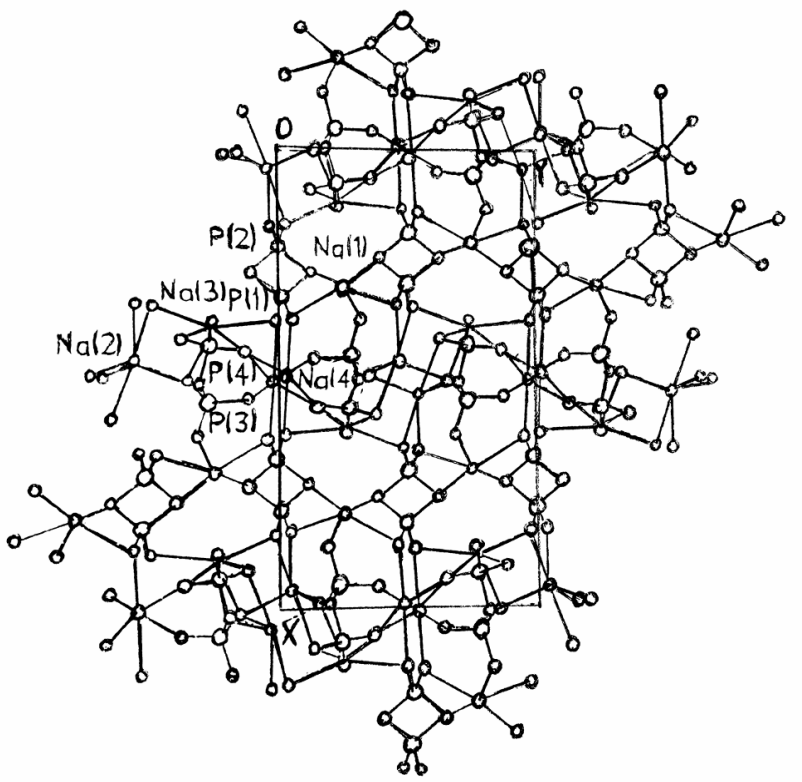

Fig. 2. Projection of $\mathrm{Na}_{4} \mathrm{Co}_{3}\left(\mathrm{PO}_{4}\right)_{2} \mathrm{P}_{2} \mathrm{O}_{7}$ on xy plane

band $\left(\sim 20000 \mathrm{~cm}^{-1}\right)$ is determined by ${ }^{4} \mathrm{~T}_{\mathrm{lg}}(\mathrm{F}) \rightarrow{ }^{4} \mathrm{~T}_{\mathrm{lg}}(\mathrm{P})$ transition, and the shoulder on the high-energy band side is determined by forbidden spin-transition or spin-orbital interaction. Within the range of ca. $14000 \mathrm{~cm}^{-1}$, a weak low-intense shoulder which is substantiated by ${ }^{4} \mathrm{~T}_{1 \mathrm{~g}}(\mathrm{~F}) \rightarrow{ }^{4} \mathrm{~A}_{2 \mathrm{~g}}$ transition is observed. However, the intensity of this transition is very weak, that is why it is seldom observed in $\mathrm{Co}$ (II) electronic spectra.

\section{Conclusions}

In the fluxes of $\mathrm{Na}_{2} \mathrm{O}-\mathrm{P}_{2} \mathrm{O}_{5}-\mathrm{CoO}$ system in the range of temperatures of $1000-650^{\circ} \mathrm{C}$, a region of crystallization of $\mathrm{Na}_{4} \mathrm{Co}_{3}\left(\mathrm{PO}_{4}\right)_{2} \mathrm{P}_{2} \mathrm{O}_{7}$ complex double phosphate have been isolated. The optimal conditions for the growth of monocrystalline compound with a high outcome (more than 4045 wt.\%) have been determined. The physical and chemical characteristics of the synthesized compound were investigated and the melting point was specified 
$\left(765^{\circ} \mathrm{C}\right)$. The complex phosphate was investigated by spectroscopic methods and complete differential thermal and chemical analyses. The crystal structure of the synthesized $\mathrm{Na}_{4} \mathrm{Co}_{3}\left(\mathrm{PO}_{4}\right)_{2} \mathrm{P}_{2} \mathrm{O}_{7}$ compound was established by $\mathrm{X}$-ray structure analysis. The following features of its structure were specified: the presence of conductivity «channels» for sodium ion along the oy axis, orthophosphate groups and nickel polyhedral are merged through common vertices and edges in imperfect spheres, perpendicular to direction [100]; and there are sodium polyhedrons with different coordination number 7,6 and 5 in the structure. Our findings can assist in the development of new materials based on the $\mathrm{Na}_{4} \mathrm{Co}_{3}\left(\mathrm{PO}_{4}\right)_{2} \mathrm{P}_{2} \mathrm{O}_{7}$ compound.

\section{REFERENCES}

1. An international initiative on long-term behavior of highlevel nuclear waste glass / Gin S., Abdelouas A., Criscenti L.J., Ebert W.L., Ferrand K., Geisler T., et al. // Mater. Today. 2013. - Vol.16. - P.243-248.

2. Harrison W.T.A., Phillips M.L.P. Syntheses, structures and properties of $\mathrm{RbScFAsO}_{4}$ and $\mathrm{CsScFAsO}_{4}$ : scandiumcontaining analogues of potassium titanyl phosphate $\left(\mathrm{KTiOPO}_{4}\right)$ // Chem. Mater. - 1999. - Vol.11. - P.3555-3560.

3. Huang $Q$., Hwu S.J. Synthesis and characterization of three new layered phosphates, $\mathrm{Na}_{2} \mathrm{MnP}_{2} \mathrm{O}_{7}, \mathrm{NaCsP}_{2} \mathrm{O}_{7}$ and $\mathrm{NaCsMn}_{0.35} \mathrm{Cu}_{0.65} \mathrm{P}_{2} \mathrm{O}_{7} / /$ Inorg. Chem. - 1998. - Vol.37. P.5869-5874.

4. Incorporation of hafnium (IV) into KTP framework from phosphate-fluoride fluxes / Zatovsky I.V., Slobodyanik N.S., Ivanenko V.I., Oseledchik Y.S., Letsenko V.Y., Ushchapivska T.I. // Cryst. Res. Technol. - 2015. - Vol.51. - P.178-182.

5. Growing and X-ray diffraction pattern of single-crystal double phosphates $\mathrm{Li}_{2} \mathrm{Mn}\left(\mathrm{PO}_{3}\right)_{4} /$ Nagorny P.G., Slobodyanik N.S., Lavrik R.V., Uschapivska T.I. // Funct. Mater. - 2018. - Vol.25. - No. 3. - P.608-612.

6. Chudinova N.N., Murashova E.V., Zaharova B.S. New complex phosphates of manganese and different metals // Zh. Neorg. Khim. - 1998. - Vol.43. - No. 6. - P.885-890.

7. Murashova E.V., Chudinova N.N. Solid phase synthesis of doubles phosphates Mn (II) and Mn (III) // Inorg. Mater. 1998. - Vol.10. - No. 34. - P.1019-1023.

8. Immobilization of cesium into mineral-like matrices of tridymite, konsarite, and langbeinite structure / Pet'kov V.I., Asabina E.A., Lukuttsov A.A., Korchemkin I.V., Alekseev A.A., Demarin V.T. // Radiochemistry. - 2015. - Vol.57. - P.632639.

9. Zinc cadmium ammine aqua monophosphate and its thermal transformations / Savchenko D.A., Kopilevich V.A., Voitenko L.V. // Russ. J. Appl. Chem. - 2008. - Vol.81. P.1492-1496.

10. The thermolysis of hydrated monophosphates of divalent transition metal / Kopilevich V.A., Voitenko L.V., Prokopchuk N.M., Savchenko D.A., Abarbarchuk L.M. // Voprosy Khimii i Khimicheskoi Tekhnologii. - 2018. - No. 4. - P.19-26.

11. Gomelya N., Ivanova V., Nosachova J. Evaluation of cationite efficiency during extraction of heavy metal ions // East Eur. J. Enterprise Technol. - 2017. - Vol.5. - No. 6. - P.4-10.

12. Nagornyj P.G., Lavrik R.V., Petrenko O.V. Synthesis of Mn (III) phosphates // Ukr. Khim. Zh. - 2002. - Vol.68. No. 7. - P.25-28.

13. Equilibrium langbeinite-related phosphates $\mathrm{Cs}_{1+\mathrm{x}} \mathrm{Ln}_{\mathrm{x}} \mathrm{Zr}_{2-\mathrm{x}}\left(\mathrm{PO}_{4}\right)_{3}(\mathrm{Ln}=\mathrm{Sm}-\mathrm{Lu})$ in the melted systems $\mathrm{Cs}_{2} \mathrm{O}-\mathrm{P}_{2} \mathrm{O}_{5}-\mathrm{LnF}_{3}-\mathrm{ZrF}_{4}$ / Ogorodnyk I.V., Baumer V.N., Zatovsky I.V., Slobodyanik N.S., Shishkin O.V., Domasevich K.V. // Acta Cryst. B. - 2007. - Vol.63. - P.819-827.

14. Sodium ion diffusion and voltage trends in phosphates $\mathrm{Na}_{4} \mathrm{M}_{3}\left(\mathrm{PO}_{4}\right)_{2} \mathrm{P}_{2} \mathrm{O}_{7}(\mathrm{M}=\mathrm{Fe}, \mathrm{Mn}, \mathrm{Co}, \mathrm{Ni})$ for possible high-rate cathodes / Wood S.M., Eames C., Kendrick E., Islam M.S. // J. Phys. Chem. C. - 2015. - Vol.119. - P.15935-15941.

15. Nagornyj P.G., Kapshuk A.A., Slobodyanik N.S. Synthesis and crystal structure of mixed sodium nickel phosphate // Zh. Neorg. Khim. - 1998. - Vol.43. - No. 9. - P.1422-1429.

Received 30.01.2021

\section{ЗМІШАНО-АНІОННИЙ ПОДВІЙНИЙ НАТРІЙ- КОБАЛЬТ(ІІ) ДІОРТОДИФОСФАТ: СТРУКТУРА ТА ВИРОЩУВАННЯ МОНОКРИСТАЛІВ}

\section{О.В. Петренко, П.Г. Нагорний, В.І. Максін, Р.В. Лаврик, В.М. Галімова}

Досліджено розчинність оксиду кобальту в розплавах $\mathrm{Na}_{2} \mathrm{O}-\mathrm{P}_{2} \mathrm{O}_{5}-\mathrm{CoO}-\mathrm{NaF}$ в широкому інтервалі мольних співвідношень $\mathrm{Na}_{2} \mathrm{O}: \mathrm{P}_{2} \mathrm{O}_{5}$ (від 0,5 до 2,0) та температур 800$900^{\circ} \mathrm{C}$ при вмісті фториду натрію в розплавах $10 \%$ та $20 \%$ (мас.). Встановлено ділянку існування складного фосфату $\mathrm{Na}_{4} \mathrm{Co}_{3}\left(\mathrm{PO}_{4}\right)_{2} \mathrm{P}_{2} \mathrm{O}_{7}$ в розплавах системи $\mathrm{Na}_{2} \mathrm{O}-\mathrm{P}_{2} \mathrm{O}_{5}-$ $\mathrm{CoO}-\mathrm{NaF}$. Синтезовану сполуку досліджено низкою фізикохімічних методів (ІЧ-спектроскопія, електронна спектроскопія дифузійного відбиття, рентгенофазовий аналіз, рентгеноструктурний аналіз, диференціальний термічний аналіз) та проведено повний хімічний аналіз, встановлено температуру плавлення одержаного фосфату $\left(765^{\circ} \mathrm{C}\right.$, без розкладання). Виконано повний рентгеноструктурний аналіз монокристалів $\mathrm{Na}_{4} \mathrm{Co}_{3}\left(\mathrm{PO}_{4}\right)_{2} \mathrm{P}_{2} \mathrm{O}_{7}$ та встановлено параметри елементарної гратки. Кристали фосфату належать до ромбічної сингонії, пр. гр. Рna2 ${ }_{1}$; параметри кристалічної решітки дорівнюють: $\mathrm{a}=18,021(1) \AA, \mathrm{b}=10,389(2) \AA, \mathrm{c}=6,532(2) \AA$, $\mathrm{V}=1222,47(1) \AA^{3}, Z=4, c_{\text {розр }}=3,47$ г $/ \mathrm{cm}^{3}$. Встановлені особливості структури синтезованого фосфату $\mathrm{Na}_{4} \mathrm{Co}_{3}\left(\mathrm{PO}_{4}\right)_{2} \mathrm{P}_{2} \mathrm{O}_{7}$ : наявність «каналів» провідності для іона натрію вздовж осі oy, присутність різнокоординованих поліедрів $\mathrm{Na}$ та Со 3 нехарактерним координаційним числом. Підібрано оптимальні умови для вирощування монокристалів складного фосфату з високим виходом за масою. Запропоновано використання синтезованої сполуки $\mathrm{Na}_{4} \mathrm{Co}_{3}\left(\mathrm{PO}_{4}\right)_{2} \mathrm{P}_{2} \mathrm{O}_{7}$ як функціонального матеріалу з іонною провідністю.

Ключові слова: фосфат, ІЧ-спектроскопія, рентгеноструктурний аналіз, рентгенофазовий аналіз, вирошування монокристалів, параметри кристалічної решітки. 


\section{MIXED ANIONIC DOUBLE SODIUM-COBALT(II) DIORTHODIPHOSPHATE: STRUCTURE AND GROWING OF SINGLE-CRYSTALS}

\author{
O.V. Petrenko ${ }^{a}$, P.G. Nagorny ${ }^{a}$, V.I. Maksyn ${ }^{b}$, R.V. Lavrik ${ }^{b, *}$, \\ V.M. Galimova ${ }^{b}$
}

a Taras Shevchenko National University of Kyiv, Kyiv, Ukraine ${ }^{b}$ National University of Life and Environmental Sciences of Ukraine, Kyiv, Ukraine

*e-mail: ruslan_lav@ukr.net

The solubility of cobalt oxide was determined in the melts of the system $\mathrm{Na}_{2} \mathrm{O}-\mathrm{P}_{2} \mathrm{O}_{5}-\mathrm{CoO}-\mathrm{NaF}$ in a wide range of molar ratios $\mathrm{Na}_{2} \mathrm{O}: \mathrm{P}_{2} \mathrm{O}_{5}(0.5-2.0)$ and temperatures of $800-900^{\circ} \mathrm{C}$ at the sodium fluoride content of $10 \mathrm{wt} . \%$ and $20 \mathrm{wt} . \%$. The region of existence and optimal conditions for growing monocrystals of complex phosphate $\mathrm{Na}_{4} \mathrm{Co}_{3}\left(\mathrm{PO}_{4}\right)_{2} \mathrm{P}_{2} \mathrm{O}_{7}$ in the melts of the system $\mathrm{Na}_{2} \mathrm{O}-\mathrm{P}_{2} \mathrm{O}_{5}-\mathrm{CoO}-\mathrm{NaF}$ was found out. The synthesized compound was investigated using a number of physicochemical methods (IR spectroscopy, diffuse reflection spectroscopy, X-ray phase analysis, X-ray structure analysis and differential thermal analysis). The complete chemical analysis of the synthesized compound was performed and the melting temperature was determined $765^{\circ} \mathrm{C}$, without decomposition). The $\mathrm{X}$-ray diffraction analysis of $\mathrm{Na}_{4} \mathrm{Co}_{3}\left(\mathrm{PO}_{4}\right)_{2} \mathrm{P}_{2} \mathrm{O}_{7}$ single crystals was carried out and the unit lattice parameters were determined. Phosphate crystals belong to the rhombic crystal system, sp. gr. Pna $2_{1}$; crystal lattice parameters are as follows: $a=18.021(1) \AA, b=10.389(2) \AA$, $\mathrm{c}=6.532(2) \AA, \mathrm{V}=1222.47(1) \AA^{3}, \mathrm{Z}=4, \mathrm{c}_{\mathrm{calc}}=3.47 \mathrm{~g} \mathrm{~cm}^{-3}$. The following specific features of the structure of complex phosphate $\mathrm{Na}_{4} \mathrm{Co}_{3}\left(\mathrm{PO}_{4}\right)_{2} \mathrm{P}_{2} \mathrm{O}_{7}$ have been established: the presence of conduction channels for the sodium ion along the oy axis and the presence of differently coordinated $\mathrm{Na}$ and $\mathrm{Co}$ polyhedra with an uncharacteristic coordination number. The optimal conditions for the growth of complex phosphate single crystals with a high weight yield were selected. The use of the synthesized compound $\mathrm{Na}_{4} \mathrm{Co}_{3}\left(\mathrm{PO}_{4}\right)_{2} \mathrm{P}_{2} \mathrm{O}_{7}$ as a functional material with ion conductivity was suggested.

Keywords: double phosphate; IR-spectroscopy; X-ray structure analysis; X-ray phase analysis; growing of single crystals; parameters of crystal lattice.

\section{REFERENCES}

1. Gin S, Abdelouas A, Criscenti LJ, Ebert WL, Ferrand K, Geisler T, et al. An international initiative on long-term behavior of high-level nuclear waste glass. Mater Today. 2013; 16: 243248. doi: 10.1016/j.mattod.2013.06.008.

2. Harrison WTA, Phillips MLP. Syntheses, structures and properties of $\mathrm{RbScFAsO}_{4}$ and $\mathrm{CsScFAsO}_{4}$ : scandium-containing analogues of potassium titanyl phosphate $\left(\mathrm{KTiOPO}_{4}\right)$. Chem Mater. 1999; 11: 3555-3560. doi: 10.1021/cm990335j.

3. Huang Q, Hwu SJ. Synthesis and characterization of three new layered phosphates, $\mathrm{Na}_{2} \mathrm{MnP}_{2} \mathrm{O}_{7}, \mathrm{NaCsP}_{2} \mathrm{O}_{7}$ and $\mathrm{NaCsMn}_{0.35} \mathrm{Cu}_{0.65} \mathrm{P}_{2} \mathrm{O}_{7}$. Inorg Chem. 1998; 37: 5869-5874. doi: 10.1021/ic980616d.
4. Zatovsky IV, Slobodyanik NS, Ivanenko VI, Oseledchik YS, Letsenko VY, Ushchapivska TI. Incorporation of hafnium (IV) into KTP framework from phosphate-fluoride fluxes. Cryst Res Technol. 2015; 51: 178-182. doi: 10.1002/crat.201500268.

5. Nagorny PG, Slobodyanik NS, Lavrik RV, Uschapivska TI. Growing and X-ray diffraction pattern of single-crystal double phosphates $\mathrm{Li}_{2} \mathrm{Mn}\left(\mathrm{PO}_{3}\right)_{4}$. Funct Mater. 2018; 25(3): 608-612. doi: $10.15407 / \mathrm{fm} 25.03 .608$.

6. Chudinova NN, Murashova EV, Zaharova BS. New complex phosphates of manganese and different metals. Zh Neorg Khim. 1998; 43(6): 885-890. (in Russian).

7. Murashova EV, Chudinova NN. Solid phase synthesis of doubles phosphates Mn (II) and Mn (III). Inorg Mater. 1998; 10(34): 1019-1023. (in Russian).

8. Pet'kov VI, Asabina EA, Lukuttsov AA, Korchemkin IV, Alekseev AA, Demarin VT. Immobilization of cesium into mineral-like matrices of tridymite, konsarite, and langbeinite structure. Radiochemistry. 2015; 57: 632-639.

doi: 10.1134/s1066362215060119.

9. Savchenko DA, Kopilevich VA, Voitenko LV. Zinc cadmium ammine aqua monophosphate and its thermal transformations. Russ J Appl Chem. 2008; 81: 1492-1496. doi: 10.1134/S1070427208090036.

10. Kopilevich VA, Voitenko LV, Prokopchuk NM, Savchenko DA, Abarbarchuk LM. The thermolysis of hydrated monophosphates of divalent transition metal. Voprosy Khimii $i$ Khimicheskoi Tekhnologii. 2018; (4): 19-26. (in Ukrainian).

11. Gomelya N, Ivanova V, Nosachova J. Evaluation of cationite efficiency during extraction of heavy metal ions. East Eur J Enterprise Technol. 2017; 5(6): 4-10.

12. Nagornyj PG, Lavrik RV, Petrenko OV. Synthesis of Mn (III) phosphates. Ukr Khim Zh. 2002; 68(7): 25-28. (in Ukrainian).

13. Ogorodnyk IV, Baumer VN, Zatovsky IV, Slobodyanik NS, Shishkin OV, Domasevich KV. Equilibrium langbeinite-related phosphates $\mathrm{Cs}_{1+\mathrm{x}} \mathrm{Ln}_{\mathrm{x}} \mathrm{Zr}_{2-\mathrm{x}}\left(\mathrm{PO}_{4}\right)_{3}(\mathrm{Ln}=\mathrm{Sm}-\mathrm{Lu})$ in the melted systems $\mathrm{Cs}_{2} \mathrm{O}-\mathrm{P}_{2} \mathrm{O}_{5}-\mathrm{LnF}_{3}-\mathrm{ZrF}_{4}$. Acta Cryst B. 2007; 63: 819827. doi: $10.1107 / \mathrm{S} 0108768107049385$.

14. Wood SM, Eames C, Kendrick E, Islam MS. Sodium ion diffusion and voltage trends in phosphates $\mathrm{Na}_{4} \mathrm{M}_{3}\left(\mathrm{PO}_{4}\right)_{2} \mathrm{P}_{2} \mathrm{O}_{7}$ $(\mathrm{M}=\mathrm{Fe}, \mathrm{Mn}, \mathrm{Co}, \mathrm{Ni})$ for possible high-rate cathodes. $J$ Phys Chem C. 2015; 119: 15935-15941. doi: 10.1021/acs.jpcc.5b04648.

15. Nagornyj PG, Kapshuk AA, Slobodyanik NS. Synthesis and crystal structure of mixed sodium nickel phosphate. Zh Neorg Khim. 1998; 43(9): 1422-1429. (in Russian). 